\title{
Discovery of the Sea Grass Halophila decipiens (Hydrocharitaceae) in the Diet of the Hawaiian Green Turtle, Cbelonia mydas ${ }^{1}$
}

\author{
Dennis 7. Russell, ${ }^{2}$ George H. Balazs, ${ }^{3}$ Ron C. Pbillips, ${ }^{4}$ and Alan K. H. Kam ${ }^{5}$
}

\begin{abstract}
The herbivorous Hawaiian green turtle (Chelonia mydas L.) has expanded its forage to include a newly reported sea grass species, Halopbila decipiens Ostenfeld, that is closely related to the previously documented food item, Halopbila bawaiiana Doty \& Stone. Halopbila decipiens was first reported in Hawai $i$ in the literature in 2001, but our investigations have found it in reef specimens preserved from 1979 and in more recent samples from green turtle forestomachs. Its presence as a dietary item indicates that green turtles probably began utilizing this species after 1998. The status of $H$. decipiens as an indigenous species to Hawai'i, its effects on turtle pastures, and the adjustment of feeding behavior of $C$. mydas to the presence of a species abundant and available as a food source are discussed.
\end{abstract}

The Hawaitan Islands are particularly vulnerable to invasion by alien plants and animals and of primary concern is the conservation of threatened and endangered species, such as the herbivorous green turtle, Chelonia mydas L. The conservation of the green turtle in Hawai' $i$ is of considerable importance and includes the protection of foraging habitats and the variety of species in the green turtle pasture ecosystems (Balazs 1980, Hirth 1997). The discovery of any new species in the green turtles' diet or habitat, such as Halopbila decipiens Ostenfeld, which is closely related to a primary food item, Halophila bawaizana Doty \& Stone, is important. This is especially the case if it is a native species with expanded distribution, or an alien species, because it

${ }^{1}$ Manuscript accepted 30 December 2002.

2 Department of Science, American University of Sharjah, P.O. Box 26666, Sharjah, United Arab Emirates (E-mail: drussell@aus.ac.ae).

${ }^{3}$ Pacific Islands Fisheries Science Center, Honolulu Laboratory, National Marine Fisheries Service, NOAA, 2570 Dole Street, Honolulu, Hawai'i 96822-2396 (E-mail: gbalazs@honlab.nmfs.hawaii.edu).

${ }^{4}$ Oktyabroskoi Revolutzii Avenue, 22/11 \#59, Sevastopol 99038, Crimea, Ukraine.

'Sea Grant Extension Service, 2525 Correa Road, HIG 213, Honolulu, Hawai'i 96822.

Pacific Science (2003), vol. 57, no. 4:393-397

(C) 2003 by University of Hawai'i Press

All rights reserved may have the potential to cause adverse effects on the natural forage of these animals.

The recent discovery of Halophila decipiens in the Hawaiian Islands (McDermid et al. 2002) prompted us to reexamine the forestomach, mouth samples, and fecal samples of green turtles we had collected from 1978 to 2001. Green turtles graze in a limited locality storing marine vegetation they eat in a forestomach or crop (Balazs et al. 1998). Upon necropsy of stranded turtles, the macerated food items in the forestomach and in fecal pellets can be identified and quantified, often to species (Russell and Balazs 2000). Turtles are natural collecting organisms, and it was largely from their forestomach and fecal samples that the distribution of the introduced red alga Hypnea musciformis (Wulfen) Lamouroux and its spread and utilization as food by $\mathrm{C}$. mydas were determined for $\mathrm{Ha}$ wai'i (Russell and Balazs 1994). Similarly, the introduction of the red alga Acantbopbora spicifera (Vahl) Boerg into Hawai'i and its subsequent dispersal during the 1950s later created a widespread and abundant major food resource used by green turtles (Doty 1961, Balazs et al. 1987, Russell 1992).

It is reasonable to assume that we missed recognizing $H$. decipiens in earlier samples because it is so similar to $H$. bawaiiana. The leaves of $H$. decipiens have serrations on the margins, are very fine and often difficult to see, and collapse upon drying. However, the 
leaf blades have distinctive abundant hairs on both leaf surfaces. There are neither teeth on the leaf margins nor hairs on the leaves of $H$. bawaiiana. A reexamination of past samples for Halophila decipiens was valuable in determining the distribution and history of this species in Hawai'i. We report on the historical presence of $H$. decipiens in Hawai'i, hypothesize about its status as an indigenous or introduced species, and discuss its increased use by marine turtles as a food source.

\section{MATERIALS AND METHODS}

All green turtle forestomach, mouth, and fecal samples that contained Halopbila that had been collected in Hawai'i since 1979 were thoroughly reexamined by microscope. Every leaf in every sample was examined to check for the presence of $H$. decipiens and $H$. bawaiiana. Also included in the examination were pressed voucher specimens of Halopbila fed to marine turtles in holding pens at the Hawai' $\mathrm{i}$ Institute of Marine Biology (HIMB), Coconut Island, Kāne'ohe Bay, O’ahu.

\section{RESULTS}

The earliest record of $H$. decipiens in our collections was from pressed specimens collected in October 1979 at HIMB. In August 1979 large amounts of a robust Halopbila (leaf blade length $20-30 \mathrm{~mm}$, width $5-10 \mathrm{~mm}$, and petiole length $10-20 \mathrm{~mm}$ ) were gathered by hand from the reef at Lilipuna Pier, near Coconut Island, and fed to green turtles held in pens for aquaculture research at HIMB. Halopbila decipiens was found to be palatable to these turtles. Three months later the area around and under the turtle holding pens was examined for the presence of this same Halopbila, and voucher specimens of plants growing there were preserved by pressing them. These same locations were examined in August 2001, but no Halopbila was present.

Out of the 61 turtle samples that contained Halopbila collected between 1978 and 2002, eight samples included $H$. decipiens and the other 53 contained $H$. bawaiiana. The samples containing $H$. decipiens from green turtles were all found after 1998; an additional four were from plants collected in the wild. Halophila decipiens was found in samples from widely separated locations on $\mathrm{O}^{\prime}$ ahu (Table 1): Hanauma Bay, Magic Island Lagoon, Iroquois Point, 'Äina Haina, Kahalu'u, and near the Ahu o Laka sandbar in Kāne'ohe Bay (Figure 1). Samples were also taken from the island of Hawai'i and Midway Atoll. Halophila decipiens was not mixed with $H$. bawaiiana in any of the turtle samples or in the reef collections except in a single reef sample $8 \mathrm{~m}$

TABLE 1

Locations of Halopbila decipiens in Green Turtle and Reef Samples

\begin{tabular}{|c|c|c|}
\hline Date & Location & Origin \\
\hline 15 October 1979 & Kāne'ohe Bay, Coconut Island, O'ahu & Reef sample, $2 \mathrm{~m}$ depth \\
\hline 28 January 1998 & Iroquois Point, $\mathrm{O}^{\prime}$ ahu & Forestomach necropsy \\
\hline 13 November 1998 & 'Āina Haina, O'ahu & Forestomach necropsy \\
\hline 16 November 2000 & Midway Atoll ${ }^{a}$ & Forestomach flush, MT no. 56 \\
\hline 17 November 2000 & Midway Atoll & Forestomach flush, MT no. 60 \\
\hline 14 November 2000 & Midway Atoll & Forestomach necropsy \\
\hline 11 April 2001 & Hanauma Bay, O'ahu & Forestomach necropsy \\
\hline 24 April 2001 & Kahalu'u, Käne'ohe Bay, O'ahu & Forestomach necropsy \\
\hline 02 June 2001 & Ahu o Laka, Kāne'ohe Bay, O'ahu & Forestomach necropsy \\
\hline 23 June 2001 & Magic Island Lagoon, O'ahu & Reef sample, 4 m depth \\
\hline 09 September 2001 & North Kohala, Hawaici Island & Reef sample, $24 \mathrm{~m}$ depth \\
\hline 13 September 2001 & Midway Atoll & Reef sample, $8 \mathrm{~m}$ depth \\
\hline
\end{tabular}

"Midway Atoll is located $2100 \mathrm{~km}$ northwest of O'ahu in the Hawaiian Archipelago.

"Hawai' Island is located $250 \mathrm{~km}$ southeast of O'ahu. 


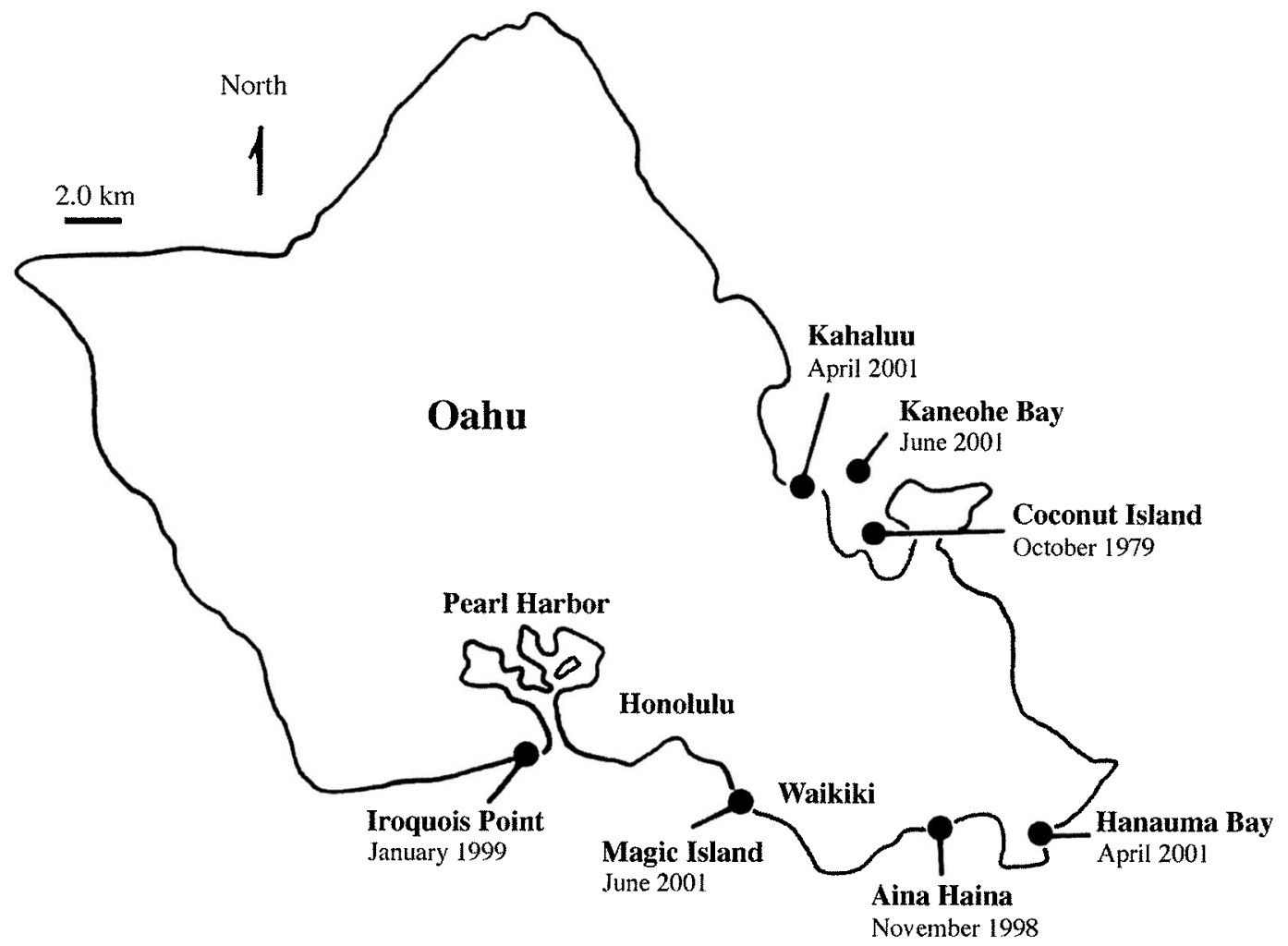

FIGURE 1. Locations of samples on O'ahu that contained Halophila decipiens.

deep at Midway Atoll (15 September 2001) where $H$. decipiens and $H$. bawaiiana leaves were found together in equal amounts.

An examination of the samples we collected from Magic Island Lagoon in the summer of 2001 confirmed the presence of Halopbila decipiens at that location. The size range of 10 leaves from $H$. decipiens from Magic Island Lagoon was $12.0-17.4 \mathrm{~mm}$ long and $3.7-5.7 \mathrm{~mm}$ wide, with a petiole length of $3.2-7.0 \mathrm{~mm}$. Hartog (1970) gave a range of $10-25 \mathrm{~mm}$ for blade length, $3-6 \mathrm{~mm}$ for blade width, and petiole length of $3-15 \mathrm{~mm}$. All other characteristics of the plants fit the description for $H$. decipiens given by Hartog (1970).

\section{DISCUSSION}

The scattered distribution of $H$. decipiens in widely separated locations of the Hawaiian
Archipelago (e.g., Midway, O'ahu [shown in Figure 1], and Hawai' $i$ Island) reported in this paper and McDermid et al. (2002) is evidence that there is no easily identifiable focal point of introduction. Species that have been introduced usually have a focal point from which they spread (Elton 1958). There was no indication that it was introduced to the HIMB area, because it was not established in the lagoon near the research laboratories before being taken there from Lilipuna Pier to feed turtles, a distance of only $0.5 \mathrm{~km}$. There is not enough evidence to speculate as to how $H$. decipiens may have come to the Hawaiian Islands, but given its broad, scattered distribution, it has probably been in the Islands at a low level and has most likely been overlooked (as we overlooked it) rather than introduced.

It is not surprising that Halopbila was present at Lilipuna Pier and HIMB in 1979 
but does not occur there today. Halopbila absence, especially after such a long period of time, is not necessarily a direct indication of grazing pressures, pollution, or human perturbation. Halophila species are very fragile vascular plants, and their roots only penetrate the substrate a few millimeters (Hartog 1970). This leaves them vulnerable to many disruptive conditions, and little is known about their physiology, durability, growth dynamics (Herbert 1986), or persistence in any specific location (Phillips and Meñez 1988).

Halopbila decipiens usually occurs in deeper water (Phillips and Meñez 1988), separate from and not in direct competition with $H$. bawaiiana. The presence of $H$. decipiens in shallower water, however, provides a more readily available food source than plants growing $24 \mathrm{~m}$ deep because turtles will be able to dive and surface to breathe with less effort. Furthermore, $H$. decipiens is not known to displace other sea grass species, so it has likely not been nor will be a threat to $H$. bazvaiiana.

The implication is that because $H$. decipiens was not found mixed with $H$. bawaiiana in turtle samples, the turtles were feeding on these two species in sufficiently separated locations that they were not eaten at the same time. The increased presence of $H$. decipiens in turtle samples after 1998 indicates that the abundance of $H$. decipiens in shallower water has just recently increased sufficiently enough for turtles to find and utilize in their diets. As $H$. decipiens becomes more abundant in Hawai' $i$ it can provide a more important food resource for green turtles (Phillips and McRoy 1980). Concomitantly, as the green turtle population in Hawai'i continues to increase and expand its range, $H$. decipiens will offer an additional source of forage possibly similar to what occurred in Hawai' $i$ following the introduction of Acantbophora spicifera and Hypnea musciformis (Balazs et al. 1987, Russell and Balazs 1994, 2000).

\section{ACKNOWLEDGMENTS}

We appreciate the valuable assistance of the following individuals in the preparation and review of this paper: George Antonelis, Shandell Eames, Francine Fiust, Allen Foley, Judy Kendig, Karla McDermid, Shawn K. K. Murakawa, Marc Rice, and Thierry Work.

\section{Literature Cited}

Balazs, G. H. 1980. Synopsis of biological data on the green turtle in the Hawaiian Islands. U.S. Dep. Commer., NOAA Tech. Memo. NMFS-SWFC-7.

Balazs, G. H., R. G. Forsyth, and A. K. H. Kam. 1987. Preliminary assessment of habitat utilization by Hawaiian green turtles in their resident foraging pastures. U.S. Dep. Commer., NOAA Tech. Memo. NMFS-SWFSC-71.

Balazs, G. H., S. K. K. Murakawa, J. Wyneken, and B. A. Schroeder. 1998. Differences in flipper size and esophagus morphology of green turtles from Hawaii and Florida. Pages 127-129 in S. P. Epperly and J. Braun (comps.), Proceedings of the 17th Annual Symposium on Sea Turtle Biology and Conservation, 4-8 March 1997, Orlando, Florida. U.S. Dep. Commer., NOAA Tech. Memo. NMFSSEFSC-415.

Doty, M. S. 1961. Acanthophora, a possible invader of the marine flora of Hawaii. Pac. Sci. 15:547-552.

Elton, C. S. 1958. The ecology of invasions by animals and plants. Methuen \& Co., London.

Hartog, C. den. 1970. The sea-grasses of the World. North-Holland Publ. Co., Amsterdam.

Herbert, D. A. 1986. The growth dynamics of Halophila bawaiiana. Aquat. Bot. 23:351-360.

Hirth, H. F. 1997. Synopsis of the biological data of the green turtle Chelonia mydas (Linnaeus 1758). U.S. Fish Wildl. Serv., U.S. Dep. Inter., Biol. Rep. 97 (1): 1-120.

McDermid, K. J., M. C. Gregoritza, and D. W. Freshwater. 2002. A new record of a second seagrass species from the Hawaiian Archipelago: Halophila decipiens Ostenfeld (Hydrocharitaceae). Aquat. Bot. 74:257262.

Phillips, R. C., and C. P. McRoy. 1980. 
Handbook of seagrass biology: An ecosystem perspective. Garland STPM Press, New York.

Phillips, R. C., and E. G. Meñez. 1988. Seagrasses. Smithson. Contrib. Mar. Sci. 34.

Russell, D. J. 1992. The ecological invasion of Hawaiian reefs by two marine red algae, Acantbophora spicifera (Vahl) Boerg. and Hypnea musciformis J. Ag. and Hypnea cervicornis J. Ag. ICES Mar. Sci. Symp. 194:110-125.
Russell, D. J., and G. H. Balazs. 1994. Colonization by the alien marine alga Hypnea musciformis (Wulfen) J. Ag. (Rhodophyta: Gigartinales) in the Hawaiian Islands and its utilization by the green turtle, Cbelonia mydas L. Aquat. Bot. 47:53-60.

. 2000. Identification manual for dietary vegetation of the Hawaiian green turtle Chelonia mydas. U.S. Dep. Commer., NOAA Tech. Memo. NMFS-SWFSC294. 